\title{
2011: the immune hallmarks of cancer
}

\author{
Federica Cavallo $\cdot$ Carla De Giovanni • \\ Patrizia Nanni • Guido Forni • Pier-Luigi Lollini
}

Received: 26 November 2010/Accepted: 27 December 2010/Published online: 26 January 2011

(C) The Author(s) 2011. This article is published with open access at Springerlink.com

\begin{abstract}
Ten years after the publication of the position paper "The hallmarks of cancer" (Hanahan and Weinberg Cell 100:57-70, 2000), it has become increasingly clear that mutated cells on their way to giving rise to a tumor have also to learn how to thrive in a chronically inflamed microenvironment, evade immune recognition, and suppress immune reactivity. Genetic and molecular definition of these three immune hallmarks of cancer offers the opportunity to learn how to deploy specific countermeasures to reverse the situation in favor of the immune system and, eventually, the patient. This new information could be channeled to address what seem to be the three major hallmarks for the immune control of cancer progression: effective procedures to activate immune reactivity; characterization of not-disposable oncoantigens; and counteraction of immune suppression.
\end{abstract}

Keywords Cancer - Inflammation - Immune surveillance · Immune suppression - Oncoantigens · Tumor vaccine Antitumor antibodies

F. Cavallo $(\bowtie) \cdot$ G. Forni

Department of Clinical and Biological Sciences,

University of Turin, Molecular Biotechnology Center,

Via Nizza 52, 10126 Turin, Italy

e-mail: federica.cavallo@unito.it

C. De Giovanni · P. Nanni

Department of Experimental Pathology,

Alma Mater Studiorum University of Bologna,

Cancer Research Section, Viale Filopanti 22,

40126 Bologna, Italy

\section{P.-L. Lollini}

Department of Hematology and Oncologic Sciences "L. \& A.

Seragnoli", Alma Mater Studiorum University of Bologna,

Cancer Research Section, Viale Filopanti 22,

40126 Bologna, Italy

\section{The immune hallmarks of cancer}

In an important position paper published in January 2000, Hanahan and Weinberg listed six alterations essential for malignant growth: self-sufficiency in growth signals, insensitivity to antigrowth signals, limitless replicative potential, ability to evade apoptosis, sustained angiogenesis, and ability to invade the tissues and metastasize [1]. The ability to deal with immune mechanisms, however, was not included among these essential capabilities, but may be supposed to be acquired by most-and perhaps all-tumors. Because of the authoritative impact of this paper, these six hallmarks are usually quoted as the starting ground for new anticancer strategies, while the addition of other critical features of malignant tumors as hallmarks is often urged [2].

In the 10 years since the publication of the paper, it has become increasingly clear that both exploitation of immune mechanisms and evasion of immune surveillance are skills that cancer cells should acquire on their way to giving rise to a tumor. A comprehensive cellular, molecular, and genetic interpretation of the initially somewhat fuzzy evidence of the importance of such acquisition has also been worked out. Three such immune hallmarks are certainly required:

1. Ability to thrive in a chronically inflamed microenvironment

2. Ability to evade immune recognition

3. Ability to suppress immune reactivity

These three capabilities and acquisition of the genetic changes required to put them into practice are constant and essential features of natural and experimental cancers. Their strength, however, may vary from one kind of tumor to another, and even more variable are the mechanisms 
through which the various types of cancer undertake these activities. Acquisition of a specific genome change, therefore, is not important, whereas acquisition of these capabilities is crucial, irrespective of the mechanisms involved.

Ability to thrive in a chronically inflamed microenvironment

Genetically modified mouse models show the intrinsic carcinogenic potency of inflammation [3-5] and permit molecular definition of several of the mechanisms whereby an incipient tumor takes advantage of an inflammatory microenvironment. Continual activation of leukocyte populations, triggered by unrelenting infections, tissue damage or the anomalous behavior of the mutated cells, contributes to the progression of neoplastic transformation with multiple mechanisms that range from reactive oxygen species to growth and angiogenic factors [6]. The balance between immunity and inflammation is constantly altered during aging, with inflammation holding the center of the stage in old age when tumor incidence peaks [7, 8].

The importance of an inflammatory microenvironment is so strong that even the time frame within which an oncogene-addicted cell population gives rise to a tumor in transgenic mice is modulated by the reactive stroma that surrounds the cancer lesion [9]. Inflammation and carcinogenesis are linked even in the absence of external inflammatory stimuli. Oncogene-driven signals activate intrinsic pro-inflammatory pathways that affect the time frame within which a carcinoma appears and progresses $[6$, 10]. Genome-wide microarray analysis in transgenic mice identifies cytokine genes whose increased expression in the tumor microenvironment is naturally induced by the transformed cells and required for their progression [11]. The inflammatory cytokines produced can be both involved in autocrine loops directly fueling tumor cell proliferation [12] and released by immune/inflammatory cells recruited to the site of epithelial transformation [13]. Inhibition of the NF-kB pathway in these immune cells modifies stroma cell components and limits tumor expansion $[14,15]$.

Murine molecular data are directly endorsed by many epidemiological studies in humans that link extrinsic and intrinsic inflammatory pathways with an increased risk of cancer [16]. The increased risk of gastric cancer in the setting of bacterial infections is linked to the polymorphisms in genes coding for pro-inflammatory cytokines [17]. These findings show how extrinsic and intrinsic inflammatory pathways conspire along the road to cancer. Molecular definition of the ways in which chronic inflammation contributes to viral, chemical, and intrinsic carcinogenesis in humans is opening up novel prospects for immunoprevention.
Ability to evade immune recognition

The immune surveillance theory was put forward in the 1960s. It defined the ability to identify and destroy nascent tumors as a central asset of the immune system [18, 19], but later received an apparently deadly blow when no increase in tumor incidence was observed in athymic nude mice [20, 21]. Work in the last 10 years, however, has shown that these mice are not an appropriate model for the investigation of immune surveillance, while the employment of genetically modified mice to generate defined and stable immune defects has fully vindicated this theory. Mice with genetic alterations leading to complete T- and B-cell deficiencies are more prone to spontaneous and chemical carcinogenesis than wild-type mice [22]. Additional gene defects affecting natural immune responses increase the risk of more aggressive and precocious tumors [22]. Moreover, immune mechanisms hold occult cancer at bay for periods equivalent to the natural life span of the mouse, while temporary immunodepression allows it to progress [23].

Immune surveillance mechanisms limit cancer development, but are not completely efficient. Tumors that eventually arise are those that are poorly or not-immunogenic [24]. A critical feature that distinguishes occult neoplastic lesions from overt cancer is thus their susceptibility to immune control. The ability to evade is another hallmark of cancer.

Data from patients with acquired immune deficiencies such as AIDS and post-transplant immune suppression show a dramatic increase in the incidence of several tumor types, including lung cancer, lymphoid tumors and tumors related to viral infections, such as Kaposi's sarcoma (human herpes virus-8) and anogenital carcinomas (human papilloma virus, HPV) [25].

In the last 10 years, it has become evident that a tumor becomes aware of its susceptibility to immune attack and elaborates many defenses against it. These have now been defined in both cellular and molecular terms.

The increasing instability of the genome of precancerous cells favors the emergence of clones of different immunogenicity. The poorly immunogenic ones are those that sneak through the meshes of immunosurveillance. The stealthiness of clinical tumors can be seen as one of the results of an effective immunosurveillance [24]. The loss or rarefaction of the expression of the glycoproteins of the major histocompatibility complex (MHC) on the cell membrane is one of the mechanisms by which tumor stealthiness is acquired. In addition, it may result from the subversion of cell physiology as a consequence of the overexpression of oncogene-coded proteins [26, 27], and alteration of antigenic peptide-processing machinery [28, 29]. 
Poor MHC glycoprotein expression and hampered antigenic peptide expression on the tumor cell surface frustrate direct recognition of tumor antigens by $\mathrm{T}$ cells and impede direct priming of an immune response by a tumor. Moreover, they make the effector phase of the T-cell reaction against tumor-associated antigens worthless. Blockage of these two functions is a crucial issue in tumor development since T-cell-mediated cytotoxicity is an effective mechanism of tumor inhibition.

\section{Ability to suppress immune reactivity}

As their growth hidden from immune recognition is not enough to allay their obsession with attacks on the part of the immune system, most-all?-tumors acquire the ability to release a series of factors and cytokines to subvert normal reaction mechanisms. When a tumor acquires the ability to release significant amounts of the colony-stimulating factors [30] or the vascular endothelial growth factor [31], it causes the expansion of a population of myeloid immature cells that may not only help tumors to suppress immune reaction but also aid in the construction of new blood vessels for tumor growth [32, 33].

Yet even this is not enough. Through direct release of transforming growth factor (TGF)-beta, IL-10, and indoleamine 2,3-dioxygenase (IDO), or through the activation of such secretions in myeloid-derived suppressor cells, tumor-associated macrophages and dendritic cells, a tumor converts naïve $\mathrm{T}$ cells into adaptive regulatory $\mathrm{T}\left(\mathrm{T}_{\mathrm{Reg}}\right)$ cells. Expansion of these cells is another way by which a tumor holds back host reactivity [34].

Tumors also exploit the physiologic role of natural $\mathrm{T}_{\mathrm{Reg}}$ cells to block immune reactions. These cells recognize with high affinity self-antigens and block the induction of autoimmunity. The overexpression of a few tolerated selfantigens, as happens during the expansion of tumor cells overexpressing oncogene products, leads to the activation of natural $\mathrm{T}_{\text {Regs. }}$. Thus, both through the exploitation of a physiologic safeguard mechanism to control autoimmunity and the ability to convert naïve $\mathrm{T}$ cells into a suppressor population, a growing tumor biases the immune response toward immunosuppression. The activation of adaptive and natural $\mathrm{T}_{\mathrm{Reg}}$ cells is triggered by specific activation of their $\mathrm{T}$-cell receptor. The $\mathrm{T}_{\text {Reg }}$ suppressor mechanisms thus turned on are mediated by different functions:

(a) Exposure on the cell membrane of molecules delivering negative signals (CTLA4 and LAG3) to dendritic cells. These signals inhibit the maturation of dendritic cells, block their expression of MHC and co-stimulatory molecules (CD80 and CD86) [35], activate their ability to produce IDO that leads to the generation of the immunosuppressive mediator kynurenine, and indirectly suppress genes encoding IL-6 and TNF [36].

(b) Release of adenosine and the secretion of TGF- $\beta$, IL10 , and IL-35 that interfere with the activation and effector functions of $\mathrm{T}$ cells $[35,37]$.

(c) Secretion of granzymes and perforin that might have cytolytic effects on target $\mathrm{T}$ cells, as well as on dendritic cells [35].

The same group of signals triggers the activation and maintenance of anomalous functions of tolerogenic dendritic cells and tumor-associated macrophages. In this way, a growing tumor orchestrates a web of distinct but integrated suppressive activities.

\section{How to counteract the immune hallmarks of cancer}

The knowledge gained in the last 10 years offers the opportunity to learn how to deploy specific countermeasures to reverse the situation in favor of the immune system and, eventually, the patient. This new information could be channeled to address what seem to be the three major hallmarks for the immune control of cancer progression:

1. Effective procedures to activate immune reactivity

2. Characterization of not-disposable oncoantigens

3. Counteract immune suppression.

Effective procedures to activate immune reactivity

Chronic inflammation can be dampened with anti-inflammatory drugs, which in some cases reduce the risk of cancer (sulindac, aspirin) [38]. However, a more sensitive strategy is to re-orient inflammation from tumor promotion to a tumor-preventive reaction [39-41]. Both passive (antibodies) and active (vaccines) immunization effectively protect the host from tumor onset [42, 43]. However, a much larger body of evidence favors active immunization.

The high efficacy of vaccines in the prevention of infection by carcinogenic viruses and other infectious agents causing cancer is currently getting an extraordinary social impact. Vaccines aimed at removing an infective risk factor are being commonly used.

Hepatocellular carcinoma accounts for more than $4 \%$ of all human cancers, and $80 \%$ of cases are associated with viral infection. Vaccination against hepatitis B virus (HBV) markedly reduced the incidence of post-hepatitis hepatocellular carcinoma [44]. Since chronic inflammation plays a significant role in the onset of liver cancer that follows HBV infection, this vaccine can be viewed as a form of primary prevention of a carcinogenic chronic inflammation. 
HPV causes neoplastic disorders ranging from benign warts to malignant cervical and anogenital carcinomas [45]. The worldwide implementation of vaccination programs against HPV began only a few years ago, and their long-term efficacy in the prevention of cervical carcinoma is not yet completely assessed. Initial results are extremely favorable, and almost complete prevention of carcinogenesis is foreseen [46]. Current HPV vaccines are effective in cancer prevention but devoid of therapeutic efficacy. Vaccines able to cure cervical carcinomas are actively studied [47].

The Epstein-Barr virus (EBV) is implicated in a variety of diseases worldwide: infectious mononucleosis in Western countries, nasopharyngeal carcinoma in Asia, Burkitt's lymphoma in Africa, and lymphoproliferative diseases in immunodeficient patients. The use of some promising candidate vaccines is being actively pursued [48, 49].

While vaccines to prevent tumors related to an infectious agent are becoming a medical reality, a large series of studies on genetically engineered mice suggest that vaccines to prevent tumors not related to an infectious agent may also be a new form of prevention [50, 51]. Numerous data on healthy mice carrying oncogenes that predestine to lethal cancer show that vaccines addressing oncogene products block the onset of neoplastic lesions. Repeated boosts of the vaccine afford a persistent protection that may last as long as the natural murine life span.

Somewhat surprisingly, the T-cell-mediated cytotoxic response plays a minor role in the protection afforded by several of these vaccines. Since the target oncogene products are self molecules, they elicit a kind of split-tolerance that mainly causes the disappearance of highaffinity $\mathrm{CD}^{+} \mathrm{T}$ cells [52]. In addition, this response is inhibited by the expansion of natural $T_{\text {Reg }}$ cells that recognize the target antigen as a self-protein [53]. Therefore, most of the antitumor action elicited by preventive vaccines rests on the multiple direct and indirect antitumor activities of antibodies [54-56].

\section{Characterization of not-disposable oncoantigens}

Vaccines that must elicit and sustain a virtually lifelong immune response carry the risk of downmodulation or loss of the target antigen by neoplastic cells. A suitable target antigen that preempts the loss of immune recognition should

(a) have an essential role in tumor growth or progression;

(b) be a target of cytotoxic cells and antibodies.

We have chosen the term "oncoantigens" for tumor antigens that fulfill these two requirements [50]. When carcinogenesis is driven by an oncoantigen, antigen-loss variants can occur, but their tumorigenic potential would be markedly impaired $[57,58]$. In the later course of tumor progression, the driving role of the targeted oncogene can be taken by different genes [59, 60], whose products, in turn, will offer further oncoantigen targets.

Tumors evade $\mathrm{T}$-cell recognition through the downmodulation of antigen-processing machinery and MHC glycoprotein expression. However, antibody recognition of accessible molecules is not affected, and antibodies still ensure a functional inhibition of the target oncoantigen together with the activation of complement-mediated cytotoxicity and ADCC. Class I oncoantigens expressed on the cell surface can be attacked by both antibodies and cellmediated immunity and are probably the best target for a preventive vaccine [50]. Class II oncoantigens are tumorsecreted molecules or molecules in the tumor microenvironment that play essential roles in tumor expansion [61]. These can be targeted by antibodies but not by T-cellmediated immunity. Class III oncoantigens are tumor molecules that cannot be reached by antibodies because of their intracellular localization, and thus can only be targeted by $\mathrm{T}$ cells $[62,63]$.

One could imagine that in the future, vaccines to prevent cancer will be administered to the general population, as is happening now to prevent infectious tumors. In a more realistic perspective, there are several human groups at risk of cancer that could benefit from specific vaccines, especially in the case of genetic risk, preneoplastic syndromes, cohorts of individuals previously exposed to environmental carcinogens, and cancer survivors with increased risk of a new primary tumor. Of particular interest appears the finding that a vaccine against ERBB2, an archetypal class I oncoantigen, impairs chemical carcinogenesis in hamsters since it may open a new way to treat healthy persons with a specific risk of a chemically induced cancer for whom no active therapeutic option exists at present [64].

\section{Counteraction of immune suppression}

The efficacy of vaccines is diminished by the tumor-driven expansion of immunosuppressive cells, including $\mathrm{T}_{\text {Reg }}$ and myeloid-derived suppressor cells (MDSC) [50], that results in both a far less significant immune response and suppression of its effector arm $[65,66]$. Strategies that counteract suppression during vaccination can make the difference between a poorly effective vaccine and a sterilizing one. $\mathrm{T}_{\mathrm{Reg}}$ cells accumulate in both human and mouse tumors, as well as in secondary lymphoid organs, and are recruited [67] and expanded by either the proliferation of preexisting $\mathrm{T}_{\mathrm{Reg}}$ cells [68] or the conversion of CD25-negative $\mathrm{T}$ cells $[34,69]$. Tumor-driven $\mathrm{T}_{\text {Reg }}$ cell expansion also changes the tumor-specific $\mathrm{T}$-cell repertoire [53, 70] and inhibits the reaction of low-avidity $\mathrm{T}$ cells against tumor antigens [53, 69]. 
When vaccination is coupled with $\mathrm{T}_{\mathrm{Reg}}$ depletion by the administration of anti-CD25 monoclonal antibody, a longlasting tumor immunity is induced, and the antibody response is enhanced. In addition, the low-avidity CTL response against the immunodominant peptide is restored, due to the freeing of $\mathrm{CD}^{+} \mathrm{T}$ cells from $\mathrm{T}_{\mathrm{Reg}}$ constraints [53]. These effects of $T_{\text {Reg }}$ depletion render the vaccination efficacious at tumor stages at which vaccination alone is ineffective [53]. Similarly, $\mathrm{T}_{\text {Reg }}$ cell functional inhibition, by means of OX40 triggering, protects mice from subsequent tumor challenge and induces a complete rejection of already-established nodules [71].

$\mathrm{T}_{\mathrm{Reg}}$ are not the sole suppressive cells than can be attacked to counteract immune suppression. Myeloidderived suppressor cells (MDSC) are an underdeveloped target of growing importance [72-74]. It has been shown that powerful vaccines inhibit MDSC [41, 75]; however, a more direct strategy can be more effective. Four lines of attack were outlined in a recent review [76]: induction of MDSC maturation, inhibition of MDSC generation, accumulation, and suppressive function.

The clinical use of antisuppressive approaches will benefit all cancer patients, in particular more advanced ones, who frequently display higher levels of immune suppression and suppressive cells. As novel immunotherapies are first tried in advanced patients, we think that the success rate of such clinical trials would be significantly enhanced by the simultaneous implementation of counter-suppression approaches.

\section{Conclusions and perspectives}

Can these three hallmarks lead to the formulation of immune procedures effective in tumor therapy? The emerging evidence shows that immune maneuvers can control cancer. This evidence is still scattered, but a series of recent reports suggest that immunotherapy is becoming a real option in the management of cancer patients. Vaccines of various kinds, in fact, have provided results equal or better than the most successful conventional treatments in a range of neoplastic diseases such as lymphomas [77], melanomas [78], prostate, and lung cancer [79]. These results along with the approval by US FDA of an initial vaccine for cancer therapy [80] will certainly spur fresh and even more rational strategies for vaccines in cancer therapy. It is thus predictable that new vaccines based on innovative technologies will progressively reach the efficacy of most conventional cancer therapies and spare patients from the devastating side effects of chemotherapy. In some cases, the cure afforded by a vaccine may prove to be even more effective, more persistent than chemotherapy.

It is noteworthy that current preclinical and clinical results converge on the relevance of antibodies in antitumor immune responses [63, 81, 82]. In the last 10 years, Herceptin and other mAbs have become efficacious new drugs that are commonly used and provide incredibly high revenues [83].

The mechanism of antitumor activity of mAb is complex and depends on the targeted antigen. mAb against Class I and Class II oncoantigens not only functionally inhibit the activity of their targets and recruit antibody-dependent killer mechanisms and complement-dependent reactions but also recruit the host adaptive response and act to some extent as a vaccine $[84,85]$. Despite these important clinical results, most antitumor vaccines are still designed to trigger only cell-mediated immunity. It is remarkable that a clinical trial of the first approved vaccine revealed significant correlations between patient survival and specific antibody titers, but not T-cell responses [80]. Probably, the time is ripe to integrate such "humoral" concepts in the design of new therapeutic cancer vaccines.

In conclusion, appraisal of the immune hallmarks of cancer, and of the possible countermeasures, opens the doors not only to widespread cancer immunoprevention but also to innovative and more efficacious cancer immunotherapies.

Acknowledgments This work was supported by the Associazione Italiana per la Ricerca sul Cancro (IG 5377 and IG 10353), the Italian Ministry for the Universities and Research, the Universities of Torino and Bologna, the Compagnia di San Paolo, the Dipartimento di Patologia Sperimentale dell’Università di Bologna (fondo "Pallotti"), the Regione Piemonte and the Italian Ministry of Health.

Open Access This article is distributed under the terms of the Creative Commons Attribution Noncommercial License which permits any noncommercial use, distribution, and reproduction in any medium, provided the original author(s) and source are credited.

\section{References}

1. Hanahan D, Weinberg RA (2000) The hallmarks of cancer. Cell 100:57-70

2. Lazebnik Y (2010) What are the hallmarks of cancer? Nat Rev Cancer 10:232-233

3. Maeda S, Kamata H, Luo JL, Leffert H, Karin M (2005) IKKbeta couples hepatocyte death to cytokine-driven compensatory proliferation that promotes chemical hepatocarcinogenesis. Cell 121:977-990. doi:10.1016/j.cell.2005.04.014

4. Karin M, Greten FR (2005) NF-kappaB: linking inflammation and immunity to cancer development and progression. Nat Rev Immunol 5:749-759. doi:10.1038/nri1703

5. Grohmann U, Bronte V (2010) Control of immune response by amino acid metabolism. Immunol Rev 236:243-264. doi: 1600-065X.2010.00915.X

6. Mantovani A, Allavena P, Sica A, Balkwill F (2008) Cancer-related inflammation. Nature 454:436-444. doi:10.1038/nature07205

7. Caruso C, Lio D, Cavallone L, Franceschi C (2004) Aging, longevity, inflammation, and cancer. Ann NY Acad Sci 1028:1-13

8. Vasto S, Carruba G, Lio D, Colonna-Romano G, Di BD, Candore G, Caruso C (2009) Inflammation, ageing and cancer. Mech Ageing Dev 130:40-45. doi:10.1016/j.mad.2008.06.003 
9. Moore RJ, Owens DM, Stamp G, Arnott C, Burke F, East N, Holdsworth H, Turner L, Rollins B, Pasparakis M, Kollias G, Balkwill F (1999) Mice deficient in tumor necrosis factor-alpha are resistant to skin carcinogenesis. Nat Med 5:828-831. doi: $10.1038 / 10552$

10. Mantovani A (2009) Cancer: Inflaming metastasis. Nature 457:36-37. doi:10.1038/457036b

11. Calogero RA, Cordero F, Forni G, Cavallo F (2007) Inflammation and breast cancer. Inflammatory component of mammary carcinogenesis in ErbB2 transgenic mice. Breast Cancer Res 9:211. doi: $10.1186 /$ bcr 1745

12. Warren MA, Shoemaker SF, Shealy DJ, Bshar W, Ip MM (2009) Tumor necrosis factor deficiency inhibits mammary tumorigenesis and a tumor necrosis factor neutralizing antibody decreases mammary tumor growth in neu/erbB2 transgenic mice. Mol Cancer Ther 8:2655-2663. doi:10.1158/1535-7163.MCT09-0358

13. Sangaletti S, Tripodo C, Ratti C, Piconese S, Porcasi R, Salcedo R, Trinchieri G, Colombo MP, Chiodoni C (2010) Oncogenedriven intrinsic inflammation induces leukocyte production of tumor necrosis factor that critically contributes to mammary carcinogenesis. Cancer Res 70:7764-7775. doi:10.1158/00085472.CAN-10-0471

14. Pikarsky E, Porat RM, Stein I, Abramovitch R, Amit S, Kasem S, Gutkovich-Pyest E, Urieli-Shoval S, Galun E, Ben-Neriah Y (2004) NF-kappaB functions as a tumour promoter in inflammation-associated cancer. Nature 431:461-466. doi:10.1038/ nature 02924

15. Greten FR, Eckmann L, Greten TF, Park JM, Li ZW, Egan LJ, Kagnoff MF, Karin M (2004) IKKbeta links inflammation and tumorigenesis in a mouse model of colitis-associated cancer. Cell 118:285-296. doi:10.1016/j.cell.2004.07.013

16. Colotta F, Allavena P, Sica A, Garlanda C, Mantovani A (2009) Cancer-related inflammation, the seventh hallmark of cancer: links to genetic instability. Carcinogenesis 30:1073-1081. doi: 10.1093/carcin/bgp127

17. El-Omar EM, Carrington M, Chow WH, McColl KE, Bream JH, Young HA, Herrera J, Lissowska J, Yuan CC, Rothman N, Lanyon G, Martin M, Fraumeni JF Jr, Rabkin CS (2000) Interleukin-1 polymorphisms associated with increased risk of gastric cancer. Nature 404:398-402. doi:10.1038/35006081

18. Thomas L (1959) Discussion. In: Lawrence HS (ed) Cellular and humoral aspects of the hypersensitivity states. Hoeber-Herper, New York, pp 529-532

19. Burnet FM (1970) The concept of immunological surveillance. Prog Exp Tumor Res 13:1-27

20. Stutman O (1974) Tumor development after 3-methylcholanthrene in immunologically deficient athymic-nude mice. Science 183:534-536

21. Rygaard J, Povlsen CO (1976) The nude mouse vs. the hypothesis of immunological surveillance. Transplant Rev 28:43-61

22. Shankaran V, Ikeda H, Bruce AT, White JM, Swanson PE, Old LJ, Schreiber RD (2001) IFNgamma and lymphocytes prevent primary tumour development and shape tumour immunogenicity. Nature 410:1107-1111. doi:10.1038/35074122

23. Koebel CM, Vermi W, Swann JB, Zerafa N, Rodig SJ, Old LJ, Smyth MJ, Schreiber RD (2007) Adaptive immunity maintains occult cancer in an equilibrium state. Nature 450:903-907. doi: 10.1038/nature06309

24. Dunn GP, Old LJ, Schreiber RD (2004) The three Es of cancer immunoediting. Annu Rev Immunol 22:329-360. doi: 10.1146/annurev.immunol.22.012703.104803

25. Grulich AE, van Leeuwen MT, Falster MO, Vajdic CM (2007) Incidence of cancers in people with HIV/AIDS compared with immunosuppressed transplant recipients: a meta-analysis. Lancet 370:59-67. doi:10.1016/S0140-6736(07)61050-2
26. Norell H, Carlsten M, Ohlum T, Malmberg KJ, Masucci G, Schedvins K, Altermann W, Handke D, Atkins D, Seliger B, Kiessling R (2006) Frequent loss of HLA-A2 expression in metastasizing ovarian carcinomas associated with genomic haplotype loss and HLA-A2-restricted HER-2/neu-specific immunity. Cancer Res 66:6387-6394. doi:10.1158/0008-5472.CAN-06-0029

27. Vertuani S, Triulzi C, Roos AK, Charo J, Norell H, Lemonnier F, Pisa P, Seliger B, Kiessling R (2009) HER-2/neu mediated downregulation of MHC class I antigen processing prevents CTLmediated tumor recognition upon DNA vaccination in HLA-A2 transgenic mice. Cancer Immunol Immunother 58:653-664. doi: 10.1007/s00262-008-0587-1

28. Garrido F, Algarra I (2001) MHC antigens and tumor escape from immune surveillance. Adv Cancer Res 83:117-158

29. Seliger B (2008) Molecular mechanisms of MHC class I abnormalities and APM components in human tumors. Cancer Immunol Immunother 57:1719-1726. doi:10.1007/s00262-008-0515-4

30. Nicoletti G, De Giovanni C, Lollini PL, Bagnara GP, Scotlandi K, Landuzzi L, Del Re B, Zauli G, Prodi G, Nanni P (1989) In vivo and in vitro production of haemopoietic colony-stimulating activity by murine cell lines of different origin: a frequent finding. Eur J Cancer Clin Oncol 25:1281-1286

31. Melani C, Chiodoni C, Forni G, Colombo MP (2003) Myeloid cell expansion elicited by the progression of spontaneous mammary carcinomas in c-erbB-2 transgenic BALB/c mice suppresses immune reactivity. Blood 102:2138-2145. doi:10.1182/blood2003-01-0190

32. McLean K, Buckanovich RJ (2008) Myeloid cells functioning in tumor vascularization as a novel therapeutic target. Transl Res 151:59-67. doi:10.1016/j.trsl.2007.11.002

33. Curiel TJ, Cheng P, Mottram P, Alvarez X, Moons L, EvdemonHogan M, Wei S, Zou L, Kryczek I, Hoyle G, Lackner A, Carmeliet P, Zou W (2004) Dendritic cell subsets differentially regulate angiogenesis in human ovarian cancer. Cancer Res 64:5535-5538. doi:10.1158/0008-5472.CAN-04-1272

34. Colombo MP, Piconese S (2007) Regulatory-T-cell inhibition versus depletion: the right choice in cancer immunotherapy. Nat Rev Cancer 7:880-887. doi:10.1038/nrc2250

35. Rochman Y, Spolski R, Leonard WJ (2009) New insights into the regulation of $\mathrm{T}$ cells by gamma(c) family cytokines. Nat Rev Immunol 9:480-490. doi:10.1038/nri2580

36. Wing K, Sakaguchi S (2010) Regulatory T cells exert checks and balances on self tolerance and autoimmunity. Nat Immunol 11:7-13. doi:10.1038/ni.1818

37. Ernst PB, Garrison JC, Thompson LF (2010) Much ado about adenosine: adenosine synthesis and function in regulatory $\mathrm{T}$ cell biology. J Immunol 185:1993-1998. doi:10.4049/jimmunol. 1000108

38. Cuzick J, Otto F, Baron JA, Brown PH, Burn J, Greenwald P, Jankowski J, La Vecchia C, Meyskens F, Senn HJ, Thun M (2009) Aspirin and non-steroidal anti-inflammatory drugs for cancer prevention: an international consensus statement. Lancet Oncol 10:501-507. doi:10.1016/S1470-2045(09)70035-X

39. Mantovani A, Romero P, Palucka AK, Marincola FM (2008) Tumour immunity: effector response to tumour and role of the microenvironment. Lancet 371:771-783. doi:10.1016/S0140-6736 (08)60241-X

40. Muller-Hermelink N, Braumuller H, Pichler B, Wieder T, Mailhammer R, Schaak K, Ghoreschi K, Yazdi A, Haubner R, Sander CA, Mocikat R, Schwaiger M, Forster I, Huss R, Weber WA, Kneilling M, Rocken M (2008) TNFR1 signaling and IFNgamma signaling determine whether $\mathrm{T}$ cells induce tumor dormancy or promote multistage carcinogenesis. Cancer Cell 13:507-518. doi:10.1016/j.ccr.2008.04.001

41. Beatty PL, Narayanan S, Gariepy J, Ranganathan S, Finn OJ (2010) Vaccine against MUC1 antigen expressed in inflammatory 
bowel disease and cancer lessens colonic inflammation and prevents progression to colitis-associated colon cancer. Cancer Prev Res (Phila) 3:438-446. doi:10.1158/1940-6207.CAPR-09-0194

42. Katsumata M, Okudaira T, Samanta A, Clark DP, Drebin JA, Jolicoeur P, Greene MI (1995) Prevention of breast tumour development in vivo by downregulation of the p185neu receptor. Nat Med 1:644-648

43. Nanni P, Nicoletti G, De Giovanni C, Landuzzi L, Di CE, Cavallo F, Pupa SM, Rossi I, Colombo MP, Ricci C, Astolfi A, Musiani P, Forni G, Lollini PL (2001) Combined allogeneic tumor cell vaccination and systemic interleukin 12 prevents mammary carcinogenesis in HER-2/neu transgenic mice. J Exp Med 194:1195-1205

44. Chang MH, You SL, Chen CJ, Liu CJ, Lee CM, Lin SM, Chu HC, Wu TC, Yang SS, Kuo HS, Chen DS (2009) Decreased incidence of hepatocellular carcinoma in hepatitis B vaccinees: a 20-year follow-up study. J Natl Cancer Inst 101:1348-1355. doi: 10.1093/jnci/djp288

45. zur Hausen H (2002) Papillomaviruses and cancer: from basic studies to clinical application. Nat Rev Cancer 2:342-350. doi: $10.1038 / \mathrm{nrc} 798$

46. Schiller JT, Castellsague X, Villa LL, Hildesheim A (2008) An update of prophylactic human papillomavirus L1 virus-like particle vaccine clinical trial results. Vaccine 26(Suppl 10):K53K61. doi:10.1016/j.vaccine.2008.06.002

47. Welters MJ, Kenter GG, van Steenwijk PJ, Lowik MJ, Berendsvan der Meer DM, Essahsah F, Stynenbosch LF, Vloon AP, Ramwadhdoebe TH, Piersma SJ, van der Hulst JM, Valentijn AR, Fathers LM, Drijfhout JW, Franken KL, Oostendorp J, Fleuren GJ, Melief CJ, van der Burg SH (2010) Success or failure of vaccination for HPV16-positive vulvar lesions correlates with kinetics and phenotype of induced T-cell responses. Proc Natl Acad Sci USA 107:11895-11899. doi:10.1073/pnas.1006500107

48. Sokal EM, Hoppenbrouwers K, Vandermeulen C, Moutschen M, Leonard P, Moreels A, Haumont M, Bollen A, Smets F, Denis M (2007) Recombinant gp350 vaccine for infectious mononucleosis: a phase 2, randomized, double-blind, placebo-controlled trial to evaluate the safety, immunogenicity, and efficacy of an Epstein-Barr virus vaccine in healthy young adults. J Infect Dis 196:1749-1753. doi:10.1086/523813

49. Rees L, Tizard EJ, Morgan AJ, Cubitt WD, Finerty S, OyewoleEletu TA, Owen K, Royed C, Stevens SJ, Shroff RC, Tanday MK, Wilson AD, Middeldorp JM, Amlot PL, Steven NM (2009) A phase I trial of epstein-barr virus gp350 vaccine for children with chronic kidney disease awaiting transplantation. Transplantation 88:1025-1029. doi:10.1097/TP.0b013e3181b9d918

50. Lollini PL, Cavallo F, Nanni P, Forni G (2006) Vaccines for tumour prevention. Nat Rev Cancer 6:204-216. doi:10.1038/ nrc 1815

51. Finn OJ (2003) Cancer vaccines: between the idea and the reality. Nat Rev Immunol 3:630-641. doi:10.1038/nri1150

52. Rolla S, Nicolo C, Malinarich S, Orsini M, Forni G, Cavallo F, Ria F (2006) Distinct and non-overlapping $T$ cell receptor repertoires expanded by DNA vaccination in wild-type and HER-2 transgenic BALB/c mice. J Immunol 177:7626-7633

53. Rolla S, Ria F, Occhipinti S, Di SG, Iezzi M, Spadaro M, Nicolo C, Ambrosino E, Merighi IF, Musiani P, Forni G, Cavallo F (2010) Erbb2 DNA vaccine combined with regulatory $T$ cell deletion enhances antibody response and reveals latent lowavidity $\mathrm{T}$ cells: potential and limits of its therapeutic efficacy. J Immunol 184:6124-6132. doi:10.4049/jimmunol.0901215

54. Nanni P, Landuzzi L, Nicoletti G, De Giovanni C, Rossi I, Croci S, Astolfi A, Iezzi M, Di CE, Musiani P, Forni G, Lollini PL (2004) Immunoprevention of mammary carcinoma in HER-2/neu transgenic mice is IFN-gamma and B cell dependent. J Immunol 173:2288-2296
55. Quaglino E, Rolla S, Iezzi M, Spadaro M, Musiani P, De Giovanni C, Lollini PL, Lanzardo S, Forni G, Sanges R, Crispi S, De LP, Calogero R, Cavallo F (2004) Concordant morphologic and gene expression data show that a vaccine halts HER-2/neu preneoplastic lesions. J Clin Invest 113:709-717. doi: 10.1172/JCI19850

56. Park JM, Terabe M, Sakai Y, Munasinghe J, Forni G, Morris JC, Berzofsky JA (2005) Early role of CD4+ Th1 cells and antibodies in HER-2 adenovirus vaccine protection against autochthonous mammary carcinomas. J Immunol 174:4228-4236

57. Nanni P, Pupa SM, Nicoletti G, De Giovanni C, Landuzzi L, Rossi I, Astolfi A, Ricci C, De VR, Invernizzi AM, Di CE, Musiani P, Forni G, Menard S, Lollini PL (2000) p185(neu) protein is required for tumor and anchorage-independent growth, not for cell proliferation of transgenic mammary carcinoma. Int $\mathrm{J}$ Cancer 87:186-194

58. Weinstein IB, Joe A (2008) Oncogene addiction. Cancer Res 68:3077-3080. doi:10.1158/0008-5472.CAN-07-3293

59. Kmieciak M, Knutson KL, Dumur CI, Manjili MH (2007) HER2/neu antigen loss and relapse of mammary carcinoma are actively induced by $\mathrm{T}$ cell-mediated anti-tumor immune responses. Eur J Immunol 37:675-685. doi:10.1002/eji.200636639

60. Jones KL, Buzdar AU (2009) Evolving novel anti-HER2 strategies. Lancet Oncol 10:1179-1187. doi: 10.1016/S1470-2045(09)70315-8

61. Cavallo F, Calogero RA, Forni G (2007) Are oncoantigens suitable targets for anti-tumour therapy? Nat Rev Cancer 7:707-713. doi: $10.1038 / \mathrm{nrc} 2208$

62. Chiarle R, Martinengo C, Mastini C, Ambrogio C, D'Escamard V, Forni G, Inghirami G (2008) The anaplastic lymphoma kinase is an effective oncoantigen for lymphoma vaccination. Nat Med 14:676-680. doi:10.1038/nm1769

63. Lollini PL, Nicoletti G, Landuzzi L, Cavallo F, Forni G, De Giovanni C, Nanni P (2011) Vaccines and other immunological approaches for cancer immunoprevention. Curr Drug Targets (in press)

64. Berta GN, Sprio AE, Iezzi M, Spadaro M, Cappia S, Salamone P, Di Scipio F, Mognetti B, Papotti M, Musiani P, Forni G, Cavallo F (2011) A DNA vaccine against ERBB2 impairs chemical carcinogenesis in random-bred hamsters. Cancer Prev Res (in press)

65. Shevach EM (2002) CD4+ CD25+ suppressor T cells: more questions than answers. Nat Rev Immunol 2:389-400. doi: $10.1038 / \mathrm{nri} 821$

66. Zou W (2005) Immunosuppressive networks in the tumour environment and their therapeutic relevance. Nat Rev Cancer 5:263-274. doi:10.1038/nrc1586

67. Curiel TJ, Coukos G, Zou L, Alvarez X, Cheng P, Mottram P, Evdemon-Hogan M, Conejo-Garcia JR, Zhang L, Burow M, Zhu Y, Wei S, Kryczek I, Daniel B, Gordon A, Myers L, Lackner A, Disis ML, Knutson KL, Chen L, Zou W (2004) Specific recruitment of regulatory $\mathrm{T}$ cells in ovarian carcinoma fosters immune privilege and predicts reduced survival. Nat Med 10:942-949. doi:10.1038/nm1093

68. Ghiringhelli F, Puig PE, Roux S, Parcellier A, Schmitt E, Solary E, Kroemer G, Martin F, Chauffert B, Zitvogel L (2005) Tumor cells convert immature myeloid dendritic cells into TGF-beta-secreting cells inducing CD4+ CD25+ regulatory $\mathrm{T}$ cell proliferation. J Exp Med 202:919-929. doi:10.1084/jem. 20050463

69. Zou W (2006) Regulatory T cells, tumour immunity and immunotherapy. Nat Rev Immunol 6:295-307. doi:10.1038/nri1806

70. Ercolini AM, Ladle BH, Manning EA, Pfannenstiel LW, Armstrong TD, Machiels JP, Bieler JG, Emens LA, Reilly RT, Jaffee EM (2005) Recruitment of latent pools of high-avidity CD8(+) T cells to the antitumor immune response. J Exp Med 201:15911602. doi: $10.1084 /$ jem. 20042167 
71. Piconese S, Valzasina B, Colombo MP (2008) OX40 triggering blocks suppression by regulatory $\mathrm{T}$ cells and facilitates tumor rejection. J Exp Med 205:825-839. doi:10.1084/jem.20071341

72. Gabrilovich DI, Nagaraj S (2009) Myeloid-derived suppressor cells as regulators of the immune system. Nat Rev Immunol 9:162-174. doi:10.1038/nri2506

73. Ostrand-Rosenberg S (2010) Myeloid-derived suppressor cells: more mechanisms for inhibiting antitumor immunity. Cancer Immunol Immunother 59:1593-1600. doi:10.1007/s00262-0100855-8

74. DeNardo DG, Andreu P, Coussens LM (2010) Interactions between lymphocytes and myeloid cells regulate pro- versus antitumor immunity. Cancer Metastasis Rev 29:309-316. doi: 10.1007/s10555-010-9223-6

75. Cipriani B, Fridman A, Bendtsen C, Dharmapuri S, Mennuni C, Pak I, Mesiti G, Forni G, Monaci P, Bagchi A, Ciliberto G, La Monica N, Scarselli E (2008) Therapeutic vaccination halts disease progression in BALB-neuT mice: the amplitude of elicited immune response is predictive of vaccine efficacy. Hum Gene Ther 19:670-680. doi:10.1089/hum.2007.127

76. Ugel S, Delpozzo F, Desantis G, Papalini F, Simonato F, Sonda N, Zilio S, Bronte V (2009) Therapeutic targeting of myeloidderived suppressor cells. Curr Opin Pharmacol 9:470-481. doi: 10.1016/j.coph.2009.06.014

77. Schuster S, Neelapu S, Gause B, Muggia F, Gockerman J, Sotomayor E, Winter J, Flowers C, Stergiou A, Kwak L, for the BiovaxID Phase III study investigators (2009) Idiotype vaccine therapy (BiovaxID) in follicular lymphoma in first complete remission: phase III clinical trial results. J Clin Oncol 27: 2
78. Schwartzentruber D, Lawson D, Richards J, Conry R, Miller D, Gailani F, Riley L, Vena D, Hwu P (2009) A phase III multiinstitutional randomized study of immunization with the gp100: 209-217(210 M) peptide followed by high-dose IL-2 compared with high-dose IL-2 alone in patients with metastatic melanoma. J Clin Oncol 27:CRA9011

79. Couzin-Frankel J (2010) Immune therapy steps up the attack. Science 330:440-443. doi:10.1126/science.330.6003.440

80. Kantoff PW, Higano CS, Shore ND, Berger ER, Small EJ, Penson DF, Redfern CH, Ferrari AC, Dreicer R, Sims RB, Xu Y, Frohlich MW, Schellhammer PF (2010) Sipuleucel-T immunotherapy for castration-resistant prostate cancer. $N$ Engl J Med 363:411-422. doi:10.1056/NEJMoa1001294

81. Nelson AL, Dhimolea E, Reichert JM (2010) Development trends for human monoclonal antibody therapeutics. Nat Rev Drug Discov 9:767-774. doi:10.1038/nrd3229

82. Weiner LM, Surana R, Wang S (2010) Monoclonal antibodies: versatile platforms for cancer immunotherapy. Nat Rev Immunol 10:317-327. doi:10.1038/nri2744

83. Wikinvest (2010) www.wikinvest.com/stock

84. Ferris RL, Jaffee EM, Ferrone S (2010) Tumor antigen-targeted, monoclonal antibody-based immunotherapy: clinical response, cellular immunity, and immunoescape. J Clin Oncol 28:43904399. doi:10.1200/JCO.2009.27.6360

85. Park S, Jiang Z, Mortenson ED, Deng L, Radkevich-Brown O, Yang X, Sattar H, Wang Y, Brown NK, Greene M, Liu Y, Tang J, Wang S, Fu YX (2010) The therapeutic effect of anti-HER2/neu antibody depends on both innate and adaptive immunity. Cancer Cell 18:160-170. doi:10.1016/j.ccr.2010.06.014 